\title{
Angiotensin II Receptor Blockade Inhibits Pneumocyte Apoptosis in Experimental Meconium Aspiration
}

\author{
HEIKKI LUKKARINEN, JUKKA LAINE, JANI LEHTONEN, ALEXANDER ZAGARIYA, \\ DHARMAPURI VIDYASAGAR, HEIKKI AHO, AND PEKKA KÄÄPÄ
}

\begin{abstract}
Research Centre of Applied and Preventive Cardiovascular Medicine [H.L., J.Le., P.K.], Department of Pathology [J.La., H.A.], and Department of Pediatrics [P.K.], University of Turku, FIN-20014 Turku, Finland; and Neonatology Research Laboratories [A.Z., D.V.], Department of Pediatrics, Michael Reese Hospital and Division of Neonatology, Department of Pediatrics, The University of Illinois at Chicago,
\end{abstract} Chicago, Illinois 60612, U.S.A.

\begin{abstract}
Lung tissue inflammation and apoptosis are implicated in the pathogenesis of meconium aspiration-induced lung injury in the newborn, but the mechanisms of these reactions are still poorly known. We investigated the time-dependent leukocyte influx and appearance of apoptosis, as well as the contribution of angioten$\sin (\mathrm{ANG})$ II receptor action on these processes in the meconium-induced lung injury. Experimental meconium aspiration was induced by intratracheal instillation of human meconium in 18 rats, and eight rats were further pretreated with an unspecific ANG II receptor inhibitor saralasin. Rats were ventilated with $60 \%$ oxygen for 1,3 , or $5 \mathrm{~h}$, and the lungs were then studied histologically for tissue injury and with DNA nick-end labeling and electron microscopy for apoptotic cell death. Lung tissue myeloperoxidase activity and expression of angiotensinogen mRNA and endothelial monocyte-activating polypeptide (EMAP) II protein were also analyzed. The meconium-instilled lungs showed increasing neutrophil migration and histologic injury after the first hour, whereas the number of epithelial apoptotic cells was elevated from the control level throughout the study. Myeloperoxidase activity was high, and the angiotensino-
\end{abstract}

\section{ABSTRACT}

gen mRNA and EMAP II protein was up-regulated at $5 \mathrm{~h}$ after the meconium insult. Pretreatment with saralasin significantly prevented the increase in lung tissue myeloperoxidase activity, EMAP II, and lung epithelial apoptosis. The results suggest that pulmonary meconium insult rapidly results in epithelial apoptosis, before significant neutrophil sequestration into the lungs. Apoptotic cell death is further connected with ANG II receptor action in the meconium-contaminated lung tissue. (Pediatr Res 55: 326-333, 2004)

ANG, angiotensin

\section{Abbreviations}

ANGEN, angiotensinogen

EMAP II, endothelial monocyte-activating polypeptide II

MAS, meconium aspiration syndrome

MPO, myeloperoxidase

RAS, renin-angiotensin system

RT-PCR, reverse transcriptase-polymerase chain reaction

TUNEL, terminal deoxynucleodityl transferase-mediated nick-end labeling
Perinatal aspiration of meconium frequently results in severe pulmonary failure with ventilation-perfusion mismatching in the lungs, hypoxemia, and increase in pulmonary vascular resistance, associated with high morbidity and mortality in fullor postterm newborn infants. The pathophysiology of the neonatal meconium aspiration syndrome (MAS) is complex, but inflammation with accumulation of polymorphonuclear

Received July 3, 2002; accepted March 6, 2003.

Correspondence: Heikki Lukkarinen, B.M., Research Centre of Applied and Preventive Cardiovascular Medicine (CAPC), University of Turku, Kiinamyllynkatu 10, FIN-20520 Turku, Finland; e-mail: heikki.lukkarinen@utu.fi

Supported by the Turku University Hospital, the Sigrid Juselius Foundation, the Paulo Foundation, and the Pediatric Research Foundation, Finland.

DOI: 10.1203/01.PDR.0000100901.88697.66 leukocytes in the pulmonary tissue is believed to be a central event in the development of acute tissue damage $(1,2)$. This inflammatory reaction is associated with increased pulmonary vascular permeability leading to proteinaceous exudation into the alveolar spaces and inactivation of the pulmonary surfactant and may together with direct toxic effects of meconium significantly contribute to the lung injury process $(1,2)$. Still, the clinical effects of anti-inflammatory therapeutic approaches and surfactant replacement treatment have often been unsatisfactory and have not consistently improved the outcome of severe complications of this disease (1-3). New advances in the pathophysiology of MAS therefore are needed.

Apoptosis, programmed cell death, is usually regarded as a physiologic mechanism in organ remodeling (4) but has been 
recently connected also to the pathogenesis of disease in various organs, including the lungs $(5,6)$. Various pathways leading to tissue apoptosis may in fact be triggered by intrinsic and extrinsic signals, such as oxidative stress and endotoxin, and thereby could contribute to the development of an acute lung disease $(5,7,8)$. Preliminary data from our laboratory have indicated increased occurrence of parenchymal cell apoptosis in the meconium-contaminated lungs of newborn piglets (9), but the initiation and mechanisms of this pulmonary cell death process in the neonatal MAS remain unclear. Similarly, although recent data suggest that apoptosis could promote accumulation of neutrophils in injured tissues (10), the interplay between apoptosis and inflammation in the meconiuminduced lung injury is still poorly defined.

There is increasing evidence to suggest that angiotensin II (ANG II) can be generated locally in the lung tissue and may have autocrine and/or paracrine actions on the cellular level (11). This local renin-angiotensin system (RAS) is shown to be functional, ANG II receptor-mediated, in the regulation of apoptosis of alveolar epithelial cells $(11,12)$. Because ANG II is further suggested to affect tissue neutrophil accumulation directly or by stimulating release of neutrophil chemoattractants from parenchymal cells $(13,14)$, we hypothesized that parenchymal apoptosis and leukocyte influx and the interactions of these injury processes in the meconium-contaminated lungs could be promoted by local ANG II action. We therefore investigated the pulmonary expression of the ANG II precursor angiotensinogen (ANGEN) and the effects of ANG II receptor blockade on lung leukocyte accumulation and appearance of apoptosis in an experimental model of meconium aspiration. We also studied the lung tissue expression of a novel proinflammatory cytokine endothelial monocyte-activating polypeptide (EMAP) II that is suggested to be released by apoptotic cells and may stimulate leukocyte migration (15). To avoid the influences of postnatal remodeling on pulmonary apoptosis, we performed our studies in mature lungs.

\section{METHODS}

\section{Animal Preparation}

Forty-two 2-mo-old male Sprague Dawley rats (mean weight $320 \mathrm{~g}$, SD $150 \mathrm{~g}$ ) were anesthetized with a mixture of fentanyl-fluanisone $(0.4 \mathrm{~mL} / \mathrm{kg}$; Hypnorm, Janssen Pharmaceutica, Beerse, Belgium) and midazolam $(0.4 \mathrm{~mL} / \mathrm{kg}$; Dormicum, Roche, Espoo, Finland) intraperitoneally, intubated through tracheostomy, and ventilated with a pressurecontrolled respirator (Baby-Bird; Bird Corp, Palm Springs, CA, U.S.A.; frequency $30 / \mathrm{min}$, peak inspiratory pressure 25 $\mathrm{cmH}_{2} \mathrm{O}$, and positive end-expiratory pressure $5 \mathrm{cmH}_{2} \mathrm{O}$ ). Anesthesia was maintained by continuous intraperitoneal infusion of Hypnorm $(0.2 \mathrm{mg} / \mathrm{h})$. The experiments were approved by the Committee of Animal Care in Research of the University of Turku.

\section{Study Protocol}

Time-dependent lung tissue changes. Lung injury was produced in 18 rats by intratracheal instillation $(2.5 \mathrm{~mL} / \mathrm{kg})$ of human meconium $(65 \mathrm{mg} / \mathrm{mL})$ (16). The pooled, lyophilized, and irradiated meconium was obtained from the first stools of several healthy term human infants. Sixteen rats with insufflation of the same amount of sterile saline into the lungs served as their controls. All of these animals were ventilated with $60 \%$ oxygen for 1,3 , or $5 \mathrm{~h}$. At the end of the experiment, animals were killed; after thoracotomy, a blood sample was taken for blood gas analysis from the left ventricle. The lungs were then perfused with $10 \mathrm{~mL}$ of saline through a pulmonary artery catheter, and lung tissue samples were obtained for the measurement of the wet/dry weight ratio and histologic and biochemical analysis.

Effects of ANG II receptor action. For studying the possible contribution of the ANG II receptor action on the inflammatory injury and appearance of pulmonary cellular apoptosis, eight rats with meconium instillation received a $1-\mathrm{mL}$ intraperitoneal injection of saralasin $(0.25 \mathrm{mg} / \mathrm{mL} ; 0.75 \mathrm{mg} / \mathrm{kg}$; Sigma Chemical Co., St. Louis, MO, U.S.A.) $30 \mathrm{~min}$ before the insult. The rats were similarly ventilated with $60 \%$ oxygen for $5 \mathrm{~h}$, and the lungs were studied as above at the end of the study.

\section{Histologic Examination}

Pulmonary tissue samples from the right lower lobe were fixed in $10 \%$ buffered formalin, embedded in paraffin. and stained with hematoxylin and eosin for the determination of the severity of lung injury. Samples were assessed by a pathologist blinded to the grouping of the rats. A score from 0 to 4 represented the percentile of affected area of the lung section ( 0 $=0 \% ; 1=1-25 \% ; 2=26-50 \% ; 3=51-75 \% ; 4=$ $76-100 \%)$ and was assigned for three different characteristics: 1) extension of pulmonary leukocyte infiltration, 2) amount of intra-alveolar leukocytes, and 3) amount of exudative debris and edema fluid. The calculated total injury score represents the sum of these scores (16).

\section{In situ Detection of Apoptotic Cells}

In situ detection of apoptotic cells in paraffin wax sections was performed as described earlier (17), with slight modifications. Briefly, deparaffinized sections were treated with 10 $\mu \mathrm{g} / \mathrm{mL}$ of proteinase $\mathrm{K}$ (Boehringer, Mannheim, Germany) at $37^{\circ} \mathrm{C}$ in $2 \mathrm{mM}$ of $\mathrm{CaCl}_{2}$ and $20 \mathrm{mM}$ of Tris-HCL (pH 7.4) for $30 \mathrm{~min}$. The endogenous peroxidase activity was blocked by incubating the slides in $0.3 \%$ hydrogen peroxide in water for $10 \mathrm{~min}$ at RT. DNA 3'-end labeling was performed after $10 \mathrm{~min}$ of incubation with terminal transferase buffer (Promega, Madison, WI, U.S.A.). The labeling mixture contained fresh terminal transferase buffer, $5 \mu \mathrm{M}$ of nonradioactive digoxigenindideoxyUTP (dig-ddUTP; Boehringer, Mannheim, Germany), $45 \mu \mathrm{M}$ of ddATP (Pharmacia, Uppsala, Sweden), and 0.34 $\mathrm{U} / \mu \mathrm{L}$ of terminal transferase (Promega). The reaction was allowed to continue for $1 \mathrm{~h}$ at $37^{\circ} \mathrm{C}$ in a humidified chamber. After washing, the slides were incubated with blocking buffer containing $2 \%(\mathrm{wt} / \mathrm{vol})$ blocking reagent and $0.05 \%(\mathrm{wt} / \mathrm{vol})$ sodium azide (Boehringer) for $30 \mathrm{~min}$. Antidigoxigenin antibody, conjugated to alkaline phosphatase (1:3000; Boehringer), in $2 \%$ (wt/vol) blocking buffer was added and incubated for $2 \mathrm{~h}$ in a humidified chamber. The slides were treated with 
alkaline phosphatase buffer $(0.1 \mathrm{M}$ of $\mathrm{NaCl}, 0.05 \mathrm{M}$ of $\mathrm{MgCl}$, and $0.1 \mathrm{M}$ of Tris- $\mathrm{HCl}, \mathrm{pH} 9.5$ ) for $10 \mathrm{~min}$. Thereafter, 337 $\mu \mathrm{g} / \mathrm{mL}$ of nitroblue tetrazolium salt (Boehringer) and 175 $\mu \mathrm{g} / \mathrm{mL}$ of 5-bromo-4-chloro-3-inodyl-phosphate (Boehringer) were added in fresh alkaline phosphatase buffer, and the reaction was terminated $3 \mathrm{~h}$ and $45 \mathrm{~min}$ later by $1 \mathrm{mM}$ of EDTA and $10 \mathrm{mM}$ of Tris-HCl (pH 8.0). Finally, the slides were mounted with Gurr Aquamount (BDH Chemicals, Poole, England). For controls, terminal transferase, dig-ddUTP, or antidigoxigenin antibody was omitted from reaction. Lymphocytes undergoing apoptosis in the lymph nodes served as a positive control.

Apoptotic cells were counted in lung sections stained with the antidigoxigenin antibody. A distinct color reaction within the cells was regarded to represent apoptotic DNA fragmentation. The results are expressed as the number of positive cells per $\mathrm{mm}^{2}$ of tissue section area in at least 10 fields of view of a $\times 10$ objective lens. The in situ detection of free DNA 3' ends is a well-established method in the detection of apoptotic cellular changes and has been validated by simultaneous electrophoretic DNA analysis in pancreatic tissue (17).

\section{Identification of Apoptosis in the Epithelial Cells}

To identify the occurrence of apoptosis in the pulmonary epithelium, we studied thin $(3 \mu \mathrm{m})$ consecutive sections of paraffin-embedded lung tissue samples. The first section was pretreated with pepsin and stained with a monoclonal mouse antibody MNF-116 (Dakopatts, Gostrup, Denmark), which recognizes type II epithelial cells $(4,18)$. Briefly, the sections were blocked with Tris-buffered saline (TBS) containing 1 $\mathrm{mg} / \mathrm{mL}$ of BSA (TBS/BSA) for $30 \mathrm{~min}$ and incubated with the antibody, diluted 1:10 in TBS, for $30 \mathrm{~min}$. After incubation, the sections were washed three times with TBS and stained with the secondary antibody. The second section was stained by the terminal deoxynucleodityl transferase-mediated nick-end labeling (TUNEL) method for the detection of the DNA fragmentation in apoptotic cells, as described above. Apoptosis was identified in the epithelium by comparing the staining of the cells in successive sections.

\section{Electron Microscopy}

Small pieces of lung tissue $\left(1 \mathrm{~mm}^{3}\right)$ from the right lower lobe were obtained for ultrastructural analysis of the alveolocapillary injury and apoptotic pulmonary cell death with electron microscopy, as described earlier (16).

\section{Myeloperoxidase Activity}

As a measure of pulmonary neutrophil influx and activation, tissue specimens of the lungs were initially frozen and later measured for myeloperoxidase (MPO) activity. After homogenization of the tissue, MPO activity was assayed spectrophotometrically using a method in which the enzyme catalyzes the oxidation of 3,3', 5,5'-tetramethylbenzidine by $\mathrm{H}_{2} \mathrm{O}_{2}$ to yield a blue chromogen with a maximum wavelength of $655 \mathrm{~nm}$ (19).

\section{Reverse Transcriptase-Polymerase Chain Reaction of Angiotensinogen mRNA}

Reverse transcriptase-polymerase chain reaction (RT-PCR) assay was performed as described earlier with slight modifications (20). Briefly, total RNA was purified using commercially available RNeasy Mini Protocol for RNA isolation from animal cells (Qiagen Co., Santa Clarita, CA, U.S.A.). The 10 $\mu \mathrm{g}$ of purified RNA was reverse transcribed using $2 \mu \mathrm{M}$ of oligo dT, $10 \mathrm{mM}$ of Tris- $\mathrm{HCl}$ ( $\mathrm{pH} 8.3$ ), $75 \mathrm{mM}$ of $\mathrm{MnCl}_{2}, 1.5$ $\mathrm{mM}$ of $\mathrm{MgCl}_{2}, 0.01 \mathrm{mM}$ of DTT, $0.2 \mathrm{mM}$ each of dNTPs, 1 $\mathrm{U} / \mu \mathrm{L}$ of RNAse inhibitor (RNasine), and $2 \mathrm{U}$ of avian myoblastosis virus reverse transcriptase (Promega), yielding a total volume of $20 \mu \mathrm{L}$ (21). The reaction was carried out for $1 \mathrm{~h}$ at $65^{\circ} \mathrm{C}$ followed by 20 cycles of PCR reaction. Obtained cDNA was used as a template in the second-step PCR reaction, which was run in Taq-polymerase buffer, supplemented with $5 \mathrm{mM}$ of $\mathrm{MgCl}_{2}, 5 \mu \mathrm{g} / \mathrm{mL}$ of each $5^{\prime}$ and $3^{\prime}$ angiotensinogen gene primers, $2 \mu \mathrm{L}$ of $10 \mathrm{mM}$ dNTPs, and $1 \mathrm{U}$ of Taq-polymerase (Promega) using a Perking Elmer PCR amplifier. Total reaction volume was $50 \mu \mathrm{L}$. Steps of the PCR reactions as well as specific angiotensinogen primers sequenced were described in detail earlier $(12,20)$. Gene expression was determined by the size of the PCR product in $1.6 \%$ agarose gels (in tris-borate buffer, $\mathrm{pH} 8.0$ ), stained by $0.1 \mu \mathrm{g} / \mathrm{mL}$ of ethidium bromide under ultraviolet light. The primers used for ANGEN in RTPCR were coding, 5'-CCTCGCTCTCTGGACTTATC-3', and uncoding, 5'-CAGACACTGAGGTGCTGTTG-3', which yielded a PCR product of 226 bp by single-step RT-PCR. The primers for $\beta$-actin were coding, 5'-CCTCGCTCTCTGGACTTATC-3', and uncoding, 5'-CAGACACTGAGGTGCTGTTG3'. For any given primer, the control and treated samples were multiplexed within the same RT-PCR. Samples were stored at $4^{\circ} \mathrm{C}$; negative controls lacked DNA. Identity of the expressed genes was determined by the expected size of the PCR product on $1.6 \%$ agarose gel. The data of the ANGEN mRNA levels was normalized against the housekeeping gene $\beta$-actin. Molecular weight markers were run in parallel.

\section{Western Blot Analysis of EMAP II}

Frozen lung samples were gently homogenized in protein extraction buffer. After removal of the cell debris by centrifugation, protein homogenate was added to sodium dodecyl sulfate-polyacrylamide gel electrophoresis loading buffer and heated for $5 \mathrm{~min}$ at $97^{\circ} \mathrm{C}$. Samples were run on a $12 \%$ sodium dodecyl sulfate-polyacrylamide gels. Western blotting was performed according to the ECL Western blotting protocol (Amersham Life Sciences, Little Chalfont, UK). EMAP II was detected with a polyclonal rabbit anti-mouse EMAP II antibody (Bender MedSystems, BMS174), diluted at 1:5000. The antibody identified both the precursor of EMAP II, pro-EMAP II $(\sim 43 \mathrm{kD})$, and the mature EMAP II $(\sim 23 \mathrm{kD})$. The proEMAP II is cleaved to its mature and active form during apoptotic processes (15). Binding of primary antibodies was detected with horseradish peroxidase-conjugated goat antirabbit immunoglobulins (diluted at 1:5000). Identity of the expressed proteins was determined by the expected size of the product on the membranes. The data of the pro- and mature 
EMAP II were normalized against the housekeeping protein $\beta$-actin.

\section{Statistical Analysis}

The results are expressed as means (SD). One-way analysis of variance (ANOVA) was used to compare the data in different groups. When the overall ANOVA was significant, comparisons between the groups were made using StudentNewman-Keuls post hoc test. Kruskal-Wallis one-way ANOVA was used for nonparametric data. Differences between two groups were evaluated by unpaired two-tailed $t$ test. A level of $p<0.05$ was considered statistically significant.

\section{RESULTS}

Instillation of meconium resulted in lowered arterial $\mathrm{pH}$ and $\mathrm{Po}_{2}$ and higher $\mathrm{PCO}_{2}$ than insufflation of saline (Table 1). Whereas the lung tissue wet/dry ratio and the total histologic injury score, regarded as signs of alveolocapillary damage, showed markedly elevated values at 3 and $5 \mathrm{~h}$ of ventilation, the total injury score was moderately raised in the meconiuminsulted lungs already at $1 \mathrm{~h}$, compared with controls (Tables 1 and 2). Accordingly, although leukocyte accumulation within the meconium-contaminated lung tissue and alveolar spaces was initially minimal, the injury score increased significantly, together with the growing amount of alveolar exudation, during the following hours (Table 2, Fig. 1). This was also reflected in the increased tissue MPO activity at $5 \mathrm{~h}$ after the insult (Fig. 2, top). However, the number of apoptotic cells, demonstrated by TUNEL staining, was significantly elevated from the control values throughout the study (Figs. 2, bottom, 3 , and 4). In consecutive sections, stained with TUNEL and MNF-116 antibody, apoptotic cell death was demonstrated mainly in the respiratory epithelium, including in type II pneumocytes (data not shown). This was also confirmed with electron microscopy (Fig. 5). In addition, expression of the tissue ANGEN mRNA and mature EMAP II protein were up-regulated in the meconium-contaminated lungs after $5 \mathrm{~h}$ of ventilation (Figs. 6 and 7).

Pretreatment of meconium-instilled animals with the ANG II receptor inhibitor saralasin did not affect the arterial $\mathrm{pH}$ or blood gas values, lung tissue wet/dry ratio, or leukocyte infiltration and total injury score but slightly increased the alveolar

Table 1. Arterial pH, blood gases, and lung tissue wet/dry ratio in rats with intratracheal meconium (Meconium) or saline (Control) instillation after 1, 3, or 5 h of ventilation

\begin{tabular}{cccccl}
\hline & $n$ & $\mathrm{pH}$ & $\mathrm{PO}_{2}(\mathrm{kPa})$ & $\mathrm{PCO}_{2}(\mathrm{kPa})$ & Wet/dry ratio \\
\hline Meconium & & & & & \\
$1 \mathrm{~h}$ & 5 & $7.41(0.11) \dagger$ & $8.0(1.1)^{*} *$ & $5.7(1.3)^{*}$ & $6.3(1.2)$ \\
$3 \mathrm{~h}$ & 5 & $7.22(0.12)^{*}$ & $15.0(5.5)^{*}$ & $8.9(3.3)^{*}$ & $5.7(0.9)^{*}$ \\
$5 \mathrm{~h}$ & 8 & $7.24(0.09)^{*}$ & $9.6(5.2)^{*}$ & $7.1(2.5)^{*}$ & $5.9(0.5)^{*}$ \\
Control & & & & & \\
$1 \mathrm{~h}$ & 3 & $7.50(0.12)$ & $31.6(8.9)$ & $3.3(0.8)$ & $4.9(0.2)$ \\
$3 \mathrm{~h}$ & 5 & $7.45(0.10)$ & $27.7(8.4)$ & $3.7(1.2)$ & $4.3(0.6)$ \\
$5 \mathrm{~h}$ & 8 & $7.43(0.11)$ & $22.7(9.1)$ & $3.5(1.1)$ & $3.9(0.8)$ \\
\hline
\end{tabular}

Data are mean (SD).

$* p<0.05$ vs control; $\uparrow p<0.05$ vs meconium 3 and $5 \mathrm{~h} ; \ddagger p<0.05$ vs meconium $3 \mathrm{~h}$.
Table 2. Histologic analysis of the lung tissue samples obtained from meconium (Meconium) or saline (Control) instilled rats after 1,3 , or 5 h of ventilation

\begin{tabular}{cccccc}
\hline & $n$ & $\begin{array}{c}\text { Leukocyte } \\
\text { infiltration }\end{array}$ & $\begin{array}{c}\text { Intra-alveolar } \\
\text { leukocytes }\end{array}$ & $\begin{array}{c}\text { Alveolar } \\
\text { exudate }\end{array}$ & $\begin{array}{c}\text { Total injury } \\
\text { score }\end{array}$ \\
\hline $\begin{array}{c}\text { Meconium } \\
1 \mathrm{~h}\end{array}$ & 5 & $1.0(0.0)^{* \dagger}$ & $1.0(0.0)^{*} \S$ & $1.4(0.5) \dagger$ & $3.4(0.5)^{*} \dagger$ \\
$3 \mathrm{~h}$ & 5 & $2.4(0.5)^{*}$ & $1.8(1.1)^{*}$ & $2.4(0.5)^{*}$ & $6.6(2.2)^{*}$ \\
$5 \mathrm{~h}$ & 8 & $2.6(0.7)^{*}$ & $2.4(0.9)^{*}$ & $2.6(0.7)^{*}$ & $7.6(2.2)^{*}$ \\
Control & & & & & \\
$1 \mathrm{~h}$ & 3 & $0.0(0.0)$ & $0.0(0.0)$ & $1.0(0.0)$ & $1.0(0.0)$ \\
$3 \mathrm{~h}$ & 5 & $0.2(0.4)$ & $0.2(0.4)$ & $0.8(0.4)$ & $1.2(1.1)$ \\
$5 \mathrm{~h}$ & 8 & $0.1(0.4)$ & $0.1(0.4)$ & $0.6(0.7)$ & $0.9(0.8)$ \\
\hline
\end{tabular}

A score from 0 to 4 was assigned for each parameter as described in Methods. Total injury score represent the sum of all these scores. Data are mean (SD).

$* p<0.05$ vs control; $\uparrow p<0.05$ vs meconium 3 and $5 \mathrm{~h} ; \ddagger p<0.01$ vs meconium $5 \mathrm{~h}$.

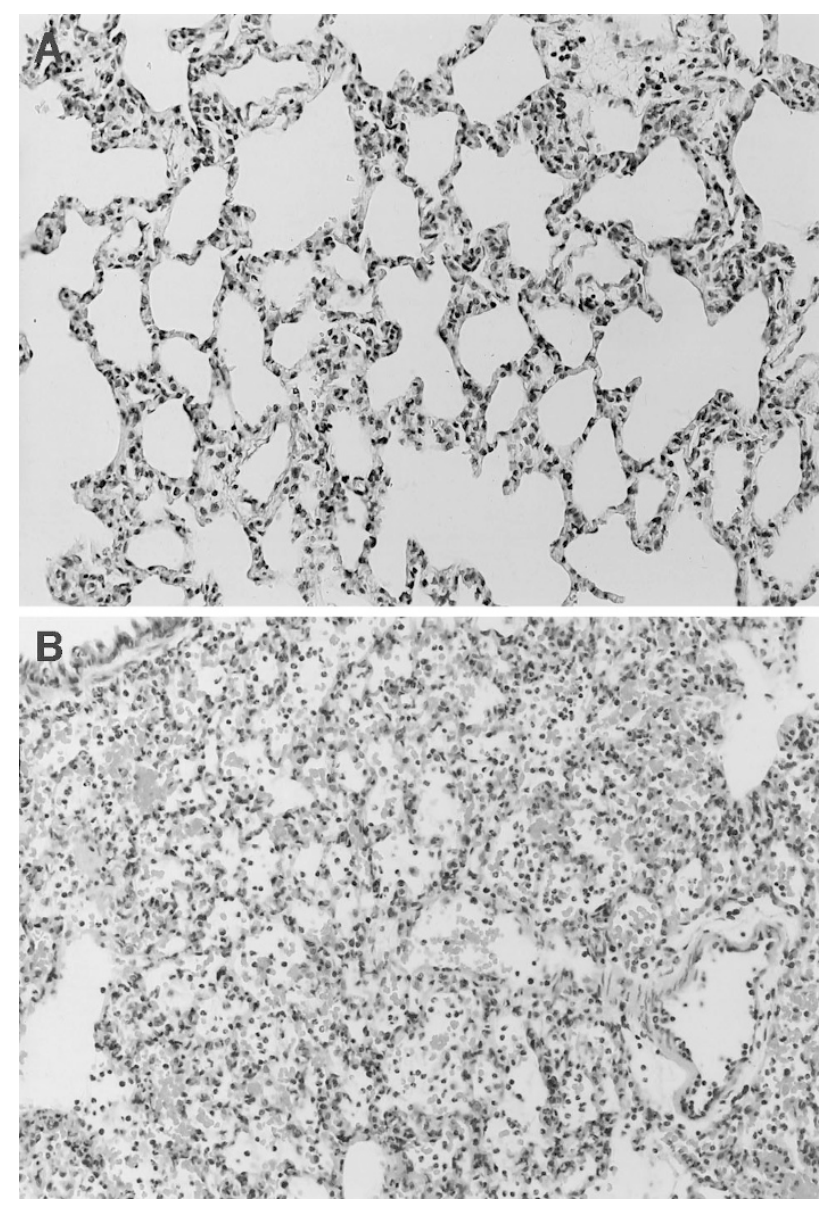

Figure 1. Lung tissue samples obtained after $5 \mathrm{~h}$ of ventilation from a control rat $(A)$ and from a meconium-instilled rat without any pretreatment $(B)$. Magnification $\times 130$ (hematoxylin-eosin).

exudate at $5 \mathrm{~h}$ (Tables 3 and 4). Moreover, pretreatment with saralasin resulted in significantly decreased MPO activity, being essentially on the control level (Fig. 2, top). However, administration of saralasin resulted in a significantly lower number of pulmonary apoptotic epithelial cells than in the insulted lungs without treatment (Fig. 2, bottom). In control lungs, saralasin had no effect on apoptosis. The concomitant 

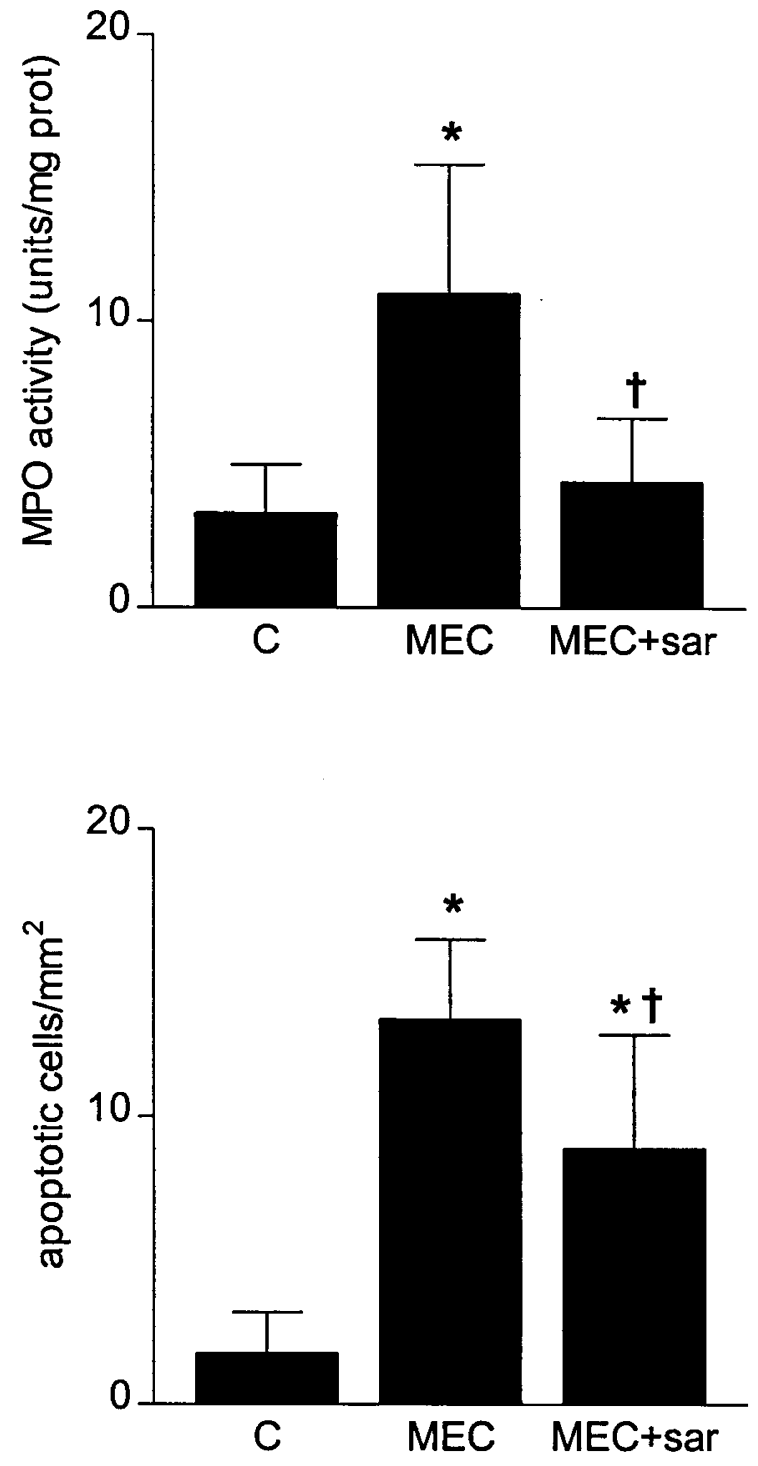

Figure 2. Lung tissue MPO activity (top) and the number of TUNEL-positive apoptotic cells $/ \mathrm{mm}^{2}$ in lung sections (bottom) obtained after $5 \mathrm{~h}$ of ventilation (mean, SD). C, control $(n=8)$; MEC, meconium $(n=8)$; MECsar, meconium + saralasin $(n=8)$ pretreatment; ${ }^{*} p<0.001 v s$ control; $\uparrow p<0.05$ vs MEC.

up-regulation of mature EMAP II in the meconiumcontaminated lungs was also prevented after saralasin pretreatment (Fig. 7).

\section{DISCUSSION}

The present data confirm previous experimental findings in piglets and rabbits indicating that meconium-induced inflammatory lung injury is associated with distinct respiratory epithelial apoptosis $(9,22)$. The results further show that this apoptotic cell death process is not dependent of significant pulmonary neutrophil accumulation and is promoted, at least in part, by ANG II receptor action in the meconium-contaminated lungs. Although the experimental lung injury in the present work was induced in fully developed lungs and the results therefore cannot be applied directly to neonatal pulmonary changes, the airway alterations in newborns tend to be more
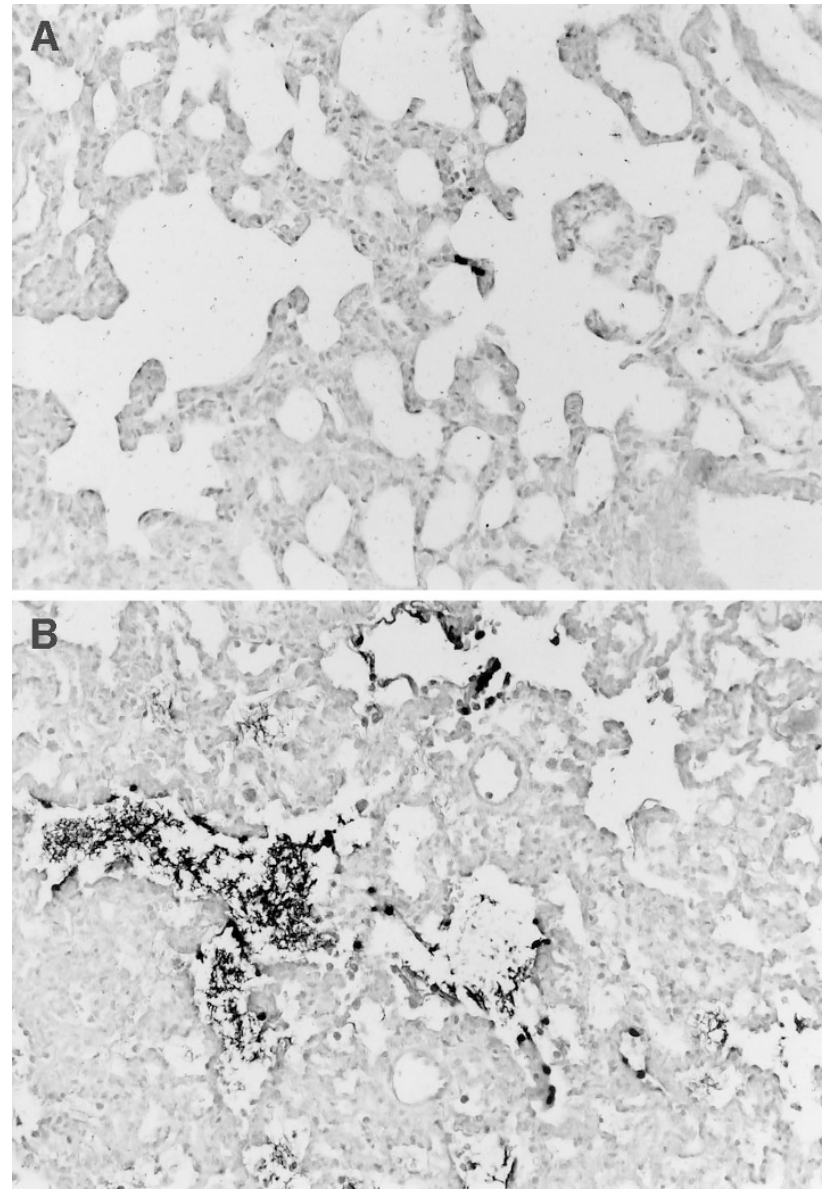

Figure 3. TUNEL-positive cells in lung tissue. Control $(A)$ and meconiumcontaminated $(B)$ lung. Intra-alveolar crystal-like deposits represent meconium $(B)$. Dark staining represents DNA fragmentation. Magnification $\times 260$.

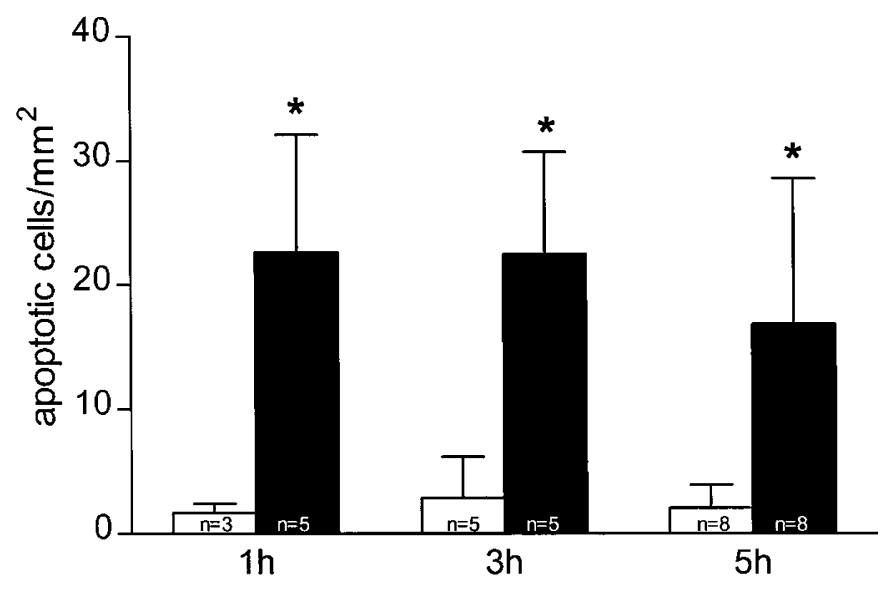

Figure 4. The number of apoptotic cells in the lung tissue of rats ventilated for 1,3 , or $5 \mathrm{~h}$ (mean, SD). $\square$, control lungs; $\boldsymbol{\square}$, meconium-contaminated lungs; ${ }^{*} p<0.01 v s$ controls.

severe than those in adult lungs in response to a pulmonary insult (23). Our experimental approach further enables us to study the appearance of apoptosis in lungs with meconium aspiration without the involvement of the active process of programmed cell death during postnatal pulmonary remodeling (4). It thus may be suggested that pulmonary epithelial apoptosis contributes to the lung damage in neonatal MAS and 

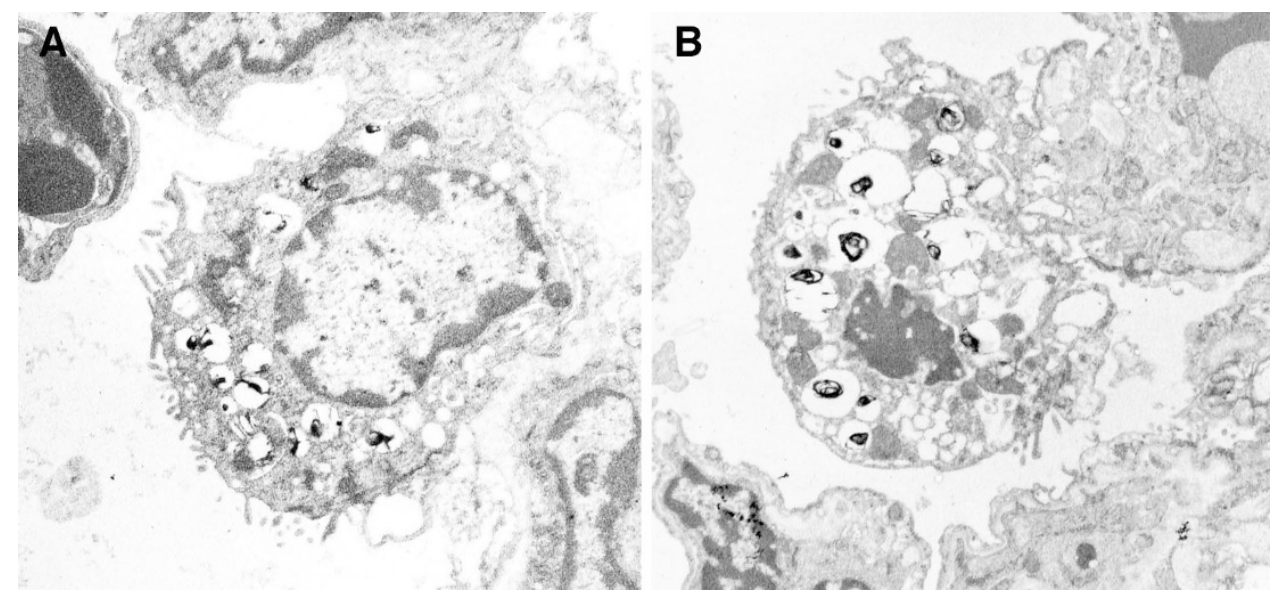

Figure 5. Electron microscopic figures of an undamaged $(A)$ and an apoptotic $(B)$ type II pneumocyte in a meconium-contaminated rat lung. The condensed chromatin represents apoptotic change. Magnification $\times 4000$.

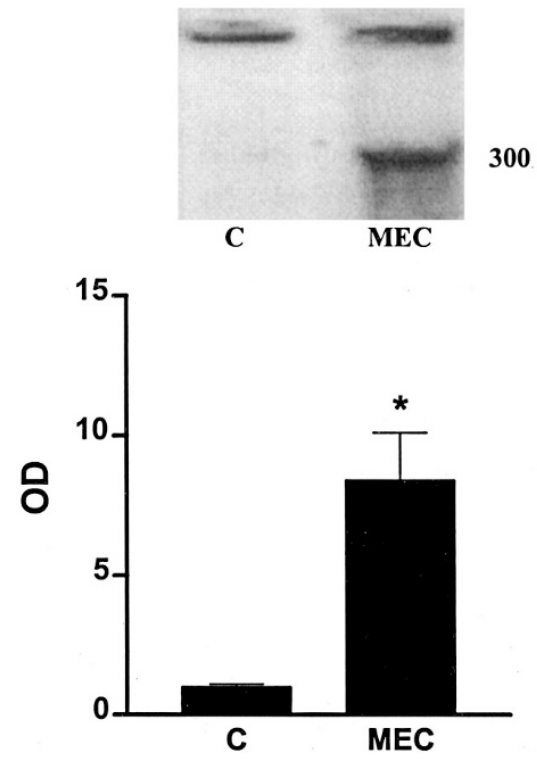

Figure 6. RT-PCR analysis of ANGEN mRNA (226 bp) in the lung tissue after $5 \mathrm{~h}$ of ventilation (top). The effect of meconium instillation on the ANGEN mRNA expression ( $n=3$ in each group; bottom). The mean level of mRNA in control lungs is expressed as $1.0( \pm \mathrm{SD})$. C, control; MEC, meconium; $* p<0.01$ vs control.

may be amenable to development of new modes of therapeutic approaches.

Although the pathogenesis of the meconium aspirationinduced lung injury is still unclear, an inflammatory process is considered to contribute to the acute respiratory failure in neonatal MAS $(1,2)$. Whereas the immediate pulmonary effects from aspirated meconium are mainly obstructive in nature (24), a subsequent intense inflammatory reaction with accumulation of activated neutrophils in the lung tissue may result in diffuse alveolar damage, inactivation of surfactant, and pulmonary failure $(25,26)$. The present data show that neutrophil sequestration into the lungs starts already within a few hours of exposure to meconium and results, as previously reported, in established inflammation of the lung tissue between 12 to $48 \mathrm{~h}$ after meconium aspiration $(25,26)$. Although the mechanisms underlying the neutrophil migration into the meconium-

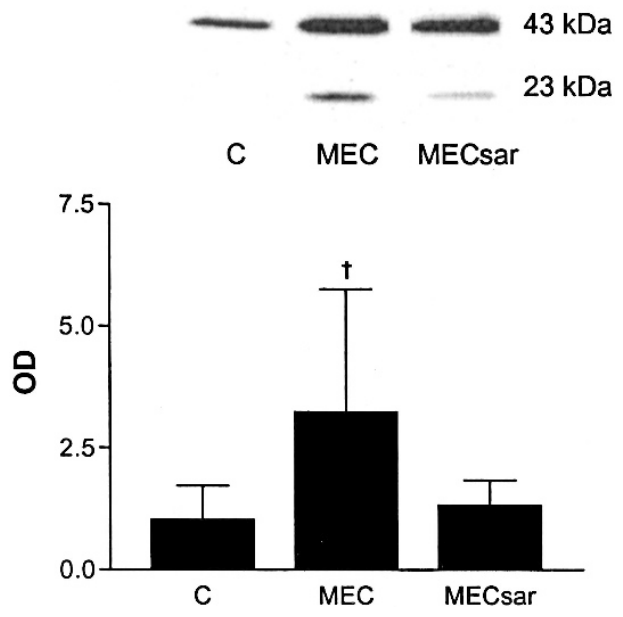

Figure 7. Western blot analysis of pro $(\sim 43 \mathrm{kD})$ and mature $(\sim 23 \mathrm{kD})$ forms of proinflammatory cytokine EMAP II in the lung tissue after $5 \mathrm{~h}$ of ventilation (top). The effect of meconium instillation with or without saralasin pretreatment on the expression of mature EMAPII ( $n=8$ in each group; bottom). C, control; MEC, meconium; MECsar, meconium + saralasin pretreatment; $\dagger p<$ 0.05 vs control and MECsar.

Table 3. Arterial pH, blood gases, and lung tissue wet/dry ratio in rats with intratracheal instillation of meconium with (Meconium + sar) or without (Meconium) saralasin pretreatment and controls (Control) after 5 h of ventilation

\begin{tabular}{lccccc}
\hline & $n$ & $\mathrm{pH}$ & $\mathrm{Po}_{2}(\mathrm{kPa})$ & $\mathrm{PCO}_{2}(\mathrm{kPa})$ & Wet/dry ratio \\
\hline Meconium & 8 & $7.24(0.09)^{*}$ & $9.6(5.2)^{*}$ & $7.1(2.5)^{*}$ & $5.9(0.5)^{*}$ \\
Meconium + sar & 8 & $7.26(0.08)^{*}$ & $11.1(7.5)^{*}$ & $6.7(1.6)^{*}$ & $6.8(1.1)^{*}$ \\
Control & 8 & $7.43(0.11)$ & $22.7(9.1)$ & $3.5(1.1)$ & $3.9(0.8)$ \\
\hline
\end{tabular}

Data are mean $(\mathrm{SD})$

sar, saralasin; $* p<0.05$ vs control.

contaminated lungs remain unclear, direct chemotactic effect or activation of alveolar macrophages by the intrapulmonary meconium have been proposed $(27,28)$. Correspondingly, we bring here evidence showing that meconium instillation is associated with stimulated pulmonary production of a novel chemotactic cytokine EMAP II, which is found to augment leukocyte migration and increase peroxidase activity in neutrophils (29). Administration of the ANG II receptor antagonist saralasin prevented the up-regulation of EMAP II and the rise 
Table 4. Histologic analysis of the lung tissue samples obtained from rats with instillation of meconium with (Meconium + sar) or without (Meconium) saralasin pretreatment and controls (Control) after 5 h of ventilation

\begin{tabular}{llllll}
\hline & & $\begin{array}{c}\text { Leukocyte } \\
\text { infiltration }\end{array}$ & $\begin{array}{c}\text { Intra-alveolar } \\
\text { leukocytes }\end{array}$ & $\begin{array}{c}\text { Alveolar } \\
\text { exudate }\end{array}$ & $\begin{array}{c}\text { Total injury } \\
\text { score }\end{array}$ \\
\hline Meconium & 8 & $2.6(0.7)^{*}$ & $2.4(0.9)^{*}$ & $2.6(0.7)^{*}$ & $7.6(2.2)^{*}$ \\
Meconium + sar & 8 & $3.1(1.1)^{*}$ & $3.0(1.1)^{*}$ & $3.4(0.5)^{* \dagger}$ & $9.5(2.4)^{*}$ \\
Control & 8 & $0.1(0.4)$ & $0.1(0.4)$ & $0.6(0.7)$ & $0.9(0.8)$ \\
\hline
\end{tabular}

A score from 0 to 4 was assigned for each parameter as described in Methods. Total injury score represent the sum of all of these scores. Data are mean (SD).

sar, saralasin; * $p<0.05$ vs control; $\uparrow p<0.05$ vs meconium.

in lung tissue MPO activity after the meconium insult, indicating that ANG II receptor action may, probably through stimulated EMAP II production, affect processes that lead to the activation of infiltrating neutrophils in this model (13). Although a direct inhibitory effect of saralasin on the neutrophil MPO release cannot be excluded in the present study, there are data indicating that saralasin does not directly influence the neutrophil activation $(13,14)$. Because, however, the histologic inflammatory injury was not reduced in the meconium-exposed lungs, the biologic significance of these inhibitory effects of saralasin remains to be evaluated.

Corroborating our earlier studies in newborn piglets (9), the meconium-induced inflammatory injury in the present model was associated with apoptotic cell death in the respiratory epithelium, including type II pneumocytes. The proapoptotic mechanisms of meconium have remained unknown, despite that components of meconium may have direct cytotoxic effects on type II pneumocytes (30). We bring here evidence suggesting that ANG II, through its receptor action, is also an important determinant in the regulation of apoptotic epithelial cell destruction in the meconium-insulted lungs. Alveolar epithelial cells are in fact capable of expressing ANGEN, angiotensin-converting enzyme, and functional ANG II receptors in vitro $(12,20)$, indicating the existence of a local RAS. This functional cascade, required for the synthesis of ANG II, may play a central role in the signaling of pulmonary parenchymal apoptosis and seems to be essential also for the alveolar epithelial apoptosis induced by Fas- and TNF- $\alpha$ in vitro (12, 20,31 ) and by intratracheal bleomycin in vivo (32). The mechanisms that lead to induction of the pulmonary RAS and ANG II receptor-dependent apoptosis after the meconium insult could not be evaluated in the present study but could be mediated through stimulated production of proapoptotic cytokines $(22,33)$.

The interplay between the pulmonary inflammatory and parenchymal cells and the role of these cellular interactions in alveolar cell death are still controversial. Although apoptosis has been traditionally considered as a mechanism promoting resolution of acute lung injury (34), there are also recent in vitro data demonstrating that neutrophils, independent of the oxidative burst, may through up-regulation of Fas and Fas ligand system induce epithelial apoptosis in the lungs (35). Similar apoptotic signaling pathway is suggested to provoke, in cooperation with intrapulmonary released cytokines, epithelial lung apoptosis in acute respiratory distress in adults (36) and after experimental intratracheal administration of bleomycin (37). In contrast, there are experimental data showing that intrapulmonary lipopolysaccharide instillation or pulmonary Fas activation leads to lung epithelial apoptotic injury that precedes leukocyte infiltration $(38,39)$. Corroborating these findings, we bring here evidence indicating that epithelial apoptosis is evident before any significant infiltration of neutrophils in the meconium-insulted lungs. The present data further show that meconium instillation is associated with pulmonary up-regulation of the proinflammatory cytokine EMAP II that is previously shown to occur coincidentally with apoptosis and contribute to recruitment of inflammatory cells to the damaged tissues $(10,15)$. Because administration of ANG II receptor antagonist saralasin prevented epithelial apoptosis and simultaneously down-regulated EMAP II expression in our model, it is possible that apoptosis-induced release of the mature EMAP II contributes to the inflammatory response in the meconium-contaminated lungs. Nevertheless, the role of EMAP II in the development of apoptosis-induced inflammation after the meconium insult still remains uncertain, especially because this polypeptide itself has been proposed to induce apoptosis (29). Similarly, although an antiapoptotic effect of saralasin through direct inhibition of neutrophil function cannot be excluded in the present study, there is evidence to suggest that saralasin does not directly influence the neutrophil activation $(13,14)$.

\section{CONLUSION}

In conclusion, our data indicate that intratracheal meconium induces apoptotic cell death in the lung epithelium independent of the pulmonary leukocyte infiltration. This pulmonary programmed cell death seems to be associated with activation of the local RAS and, unlike the inflammatory injury, is connected with ANG II receptor action in the meconiumcontaminated lungs. Thus, these early pulmonary processes potentially provide new insight into the pathogenesis and treatment of neonatal MAS.

Acknowledgments. We thank Tiina Peromaa and Pauliina Penttinen for excellent technical assistance.

\section{REFERENCES}

1. Jobe AH, Ikegami M 1998 Mechanisms initiating lung injury in the preterm. Early Hum Dev 53:81-94

2. Cleary GM, Wiswell TE 1998 Meconium-stained amniotic fluid and the meconium aspiration syndrome. An update. Pediatr Clin North Am 45:511-529

3. Wiswell TE, Knight GR, Finer NN, Donn SM, Desai H, Walsh WF, Sekar KC, Bernstein G, Keszler M, Visser VE, Merritt TA, Mannino FL, Mastrioianni L, Marcy B, Revak SD, Tsai H, Cochrane CG 2002 A multicenter, randomized, controlled trial comparing Surfaxin (Lucinactant) lavage with standard care for treatment of meconium aspiration syndrome. Pediatrics 109:1081-1087

4. Schittny JC, Djonov V, Fine A, Burri PH 1998 Programmed cell death contributes to postnatal lung development. Am J Respir Cell Mol Biol 18:786-793

5. Fine A, Janssen-Heininger Y, Soultanakis RP, Swisher SG, Uhal BD 2000 Apoptosis in lung pathophysiology. Am J Physiol 279:L423-L427

6. Thompson CB 1995 Apoptosis in the pathogenesis and treatment of disease. Science 267:1456-1462

7. Kazzaz JA, Xu J, Palaia TA, Mantell L, Fein AM, Horowitz S 1996 Cellular oxygen toxicity. Oxidant injury without apoptosis. J Biol Chem 271:15182-15186

8. Kawasaki M, Kuwano K, Hagimoto N, Matsuba T, Kunitake R, Tanaka T, Maeyama T, Hara N 2000 Protection from lethal apoptosis in lipopolysaccharide-induced acute lung injury in mice by a caspase inhibitor. Am J Pathol 157:597-603 
9. Holopainen R, Aho H, Laine J, Peuravuori H, Soukka H, Kaapa P 1999 Human meconium has high phospholipase A2 activity and induces cellular injury and apoptosis in piglet lungs. Pediatr Res 46:626-632

10. Daemen MA, van't Veer C, Denecker G, Heemskerk VH, Wolfs TG, Clauss M, Vandenabeele P, Buurman WA 1999 Inhibition of apoptosis induced by ischemiareperfusion prevents inflammation. J Clin Invest 104:541-549

11. Filippatos G, Tilak M, Pinillos H, Uhal BD 2001 Regulation of apoptosis by angiotensin II in the heart and lungs. Int J Mol Med 7:273-280

12. Wang R, Zagariya A, Ibarra-Sunga O, Gidea C, Ang E, Deshmukh S, Chaudhary G, Baraboutis J, Filippatos G, Uhal BD 1999 Angiotensin II induces apoptosis in human and rat alveolar epithelial cells. Am J Physiol 276:L885-L889

13. Farber HW, Center DM, Rounds S, Danilov SM 1990 Components of the angiotensin system cause release of a neutrophil chemoattractant from cultured bovine and human endothelial cells. Eur Heart J 11(suppl B):100-107

14. Raiden S, Pereyra Y, Nahmod V, Alvarez C, Castello L, Giordano M, Geffner J 2000 Losartan, a selective inhibitor of subtype AT1 receptors for angiotensin II, inhibits neutrophil recruitment in the lung triggered by fMLP. J Leukoc Biol 68:700-706

15. Knies UE, Behrensdorf HA, Mitchell CA, Deutsch U, Risau W, Drexler HC, Claus M 1998 Regulation of endothelial monocyte-activating polypeptide II release by apoptosis. Proc Natl Acad Sci U S A 95:12322-12327

16. Holopainen R, Aho H, Laine J, Halkola L, Kaapa P 1999 Nitric oxide inhalation inhibits pulmonary apoptosis but not inflammatory injury in porcine meconium aspiration. Acta Paediatr 88:1147-1155

17. Laine VJO, Nyman KM, Peuravuori HJ, Henriksen K, Parvinen M, Nevalainen TJ 1996 Lipopolysaccharide induced apoptosis of rat pancreatic acinar cells. Gut 38:747-752

18. Kasper M, Rudolf T, Verhofstad AA, Schuh D, Muller M 1993 Heterogeneity in the immunolocalization of cytokeratin-specific monoclonal antibodies in the rat lung: evaluation of three different alveolar epithelial cell types. Histochemistry 100:65-71

19. Grisham MB, Benoit JN, Granger DN 1990 Assessment of leukocyte involvemen during ischemia and reperfusion of intestine. Methods Enzymol 186:729-742

20. Wang R, Zagariya A, Ang E, Ibarra-Sunga O, Uhal BD 1999 Fas-induced apoptosis of alveolar epithelial cells requires ANG II generation and receptor interaction. Am J Physiol 277:L1245-L1250

21. Marquardt O, Straub OC, Ahl R, Haas B 1995 Detection of foot-and-mouth disease virus in nasal swabs of asymptomatic cattle by RT-PCR within 24 hours. J Virol Methods 53:255-261

22. Zagariya ABR, Uhal B, Navale S, Freidine M, Vidyasagar D 2000 Cell death and lung cell histology in meconium aspirated newborn rabbit lung. Eur J Pediatr 159:819

23. Coalson JJ, Kuehl TJ, Prihoda TJ, deLemos RA 1988 Diffuse alveolar damage in the evolution of bronchopulmonary dysplasia in the baboon. Pediatr Res 24:357-366

24. Tran N, Lowe C, Sivieri EM, Shaffer TH 1980 Sequential effects of acute meconium obstruction on pulmonary function. Pediatr Res 14:34-38

25. Tyler DC, Murphy J, Cheney FW 1978 Mechanical and chemical damage to lung tissue caused by meconium aspiration. Pediatrics 62:454-459
26. Davey AM, Becker JD, Davis JM 1993 Meconium aspiration syndrome: physiological and inflammatory changes in a newborn piglet model. Pediatr Pulmonol 16:101108

27. Kojima T, Hattori K, Fujiwara T, Sasai-Takedatsu M, Kobayashi Y 1994 Meconiuminduced lung injury mediated by activation of alveolar macrophages. Life Sci 54:1559-1562

28. de Beaufort AJ, Pelikan DM, Elferink JG, Berger HM 1998 Effect of interleukin 8 in meconium on in-vitro neutrophil chemotaxis. Lancet 352:102-105

29. Tas MP, Murray JC 1996 Endothelial-monocyte-activating polypeptide II. Int J Biochem Cell Biol 28:837-841

30. Oelberg DG, Downey SA, Flynn MM 1990 Bile salt-induced intracellular $\mathrm{Ca}++$ accumulation in type II pneumocytes. Lung 168:297-308

31. Wang R, Alam G, Zagariya A, Gidea C, Pinillos H, Lalude O, Choudhary G, Oezatalay D, Uhal BD 2000 Apoptosis of lung epithelial cells in response to TNF-alpha requires angiotensin II generation de novo. J Cell Physiol 185:253259

32. Wang R, Ibarra-Sunga O, Verlinski L, Pick R, Uhal BD 2000 Abrogation of bleomycin-induced epithelial apoptosis and lung fibrosis by captopril or by a caspase inhibitor. Am J Physiol 279:L143-L151

33. Jones CA, Cayabyab RG, Kwong KY, Stotts C, Wong B, Hamdan H, Minoo P, deLemos RA 1996 Undetectable interleukin (IL)-10 and persistent IL-8 expression early in hyaline membrane disease: a possible developmental basis for the predisposition to chronic lung inflammation in preterm newborns. Pediatr Res 39:966-975

34. Bardales RH, Xie SS, Schaefer RF, Hsu SM 1996 Apoptosis is a major pathway responsible for the resolution of type II pneumocytes in acute lung injury. Am J Pathol 149:845-852

35. Serrao KL, Fortenberry JD, Owens ML, Harris FL, Brown LA 2001 Neutrophils induce apoptosis of lung epithelial cells via release of soluble Fas ligand. Am J Physiol 280:L298-L305

36. Matute-Bello G, Liles WC, Steinberg KP, Kiener PA, Mongovin S, Chi EY, Jonas M, Martin TR 1999 Soluble Fas ligand induces epithelial cell apoptosis in humans with acute lung injury (ARDS). J Immunol 163:2217-2225

37. Hagimoto N, Kuwano K, Nomoto Y, Kunitake R, Hara N 1997 Apoptosis and expression of Fas/Fas ligand mRNA in bleomycin-induced pulmonary fibrosis in mice. Am J Respir Cell Mol Biol 16:91-101

38. Vernooy JH, Dentener MA, van Suylen RJ, Buurman WA, Wouters EF 2001 Intratracheal instillation of lipopolysaccharide in mice induces apoptosis in bronchial epithelial cells: no role for tumor necrosis factor-alpha and infiltrating neutrophils. Am J Respir Cell Mol Biol 24:569-576

39. Matute-Bello G, Winn RK, Jonas M, Chi EY, Martin TR, Liles WC 2001 Fas (CD95) induces alveolar epithelial cell apoptosis in vivo: implications for acute pulmonary inflammation Am J Pathol 158:153-161 